\title{
Dis-adoption of Household Biogas technologies in Central Uganda
}

\author{
Lwiza Florence ${ }^{\mathrm{ac}}$, Johnny Mugisha ${ }^{\mathrm{a}}$, Walekhwa N Peter ${ }^{\mathrm{a}}$, Bedru Balana ${ }^{\mathrm{b}}$, Jo Smith ${ }^{\mathrm{d}}$
}

${ }^{a}$ Department of Agribusiness and Natural Resource Economics, Makerere University, Uganda

${ }^{\mathrm{b}}$ International Water Management Institute (IWMI), Accra, Ghana

c Department of Agricultural Economics, Kansas State University

${ }^{\mathrm{d}}$ Aberdeen University

\section{*Florence Lwiza}

Assistant Lecturer

Department of Agribusiness and Natural Resource Economics, Makerere University

PO Box 7062 Kampala, Uganda.

Current address

PhD Student, Department of Agricultural Economics, Kansas State University.

66502 Manhattan- KS

Telephone +1 7854733860

Email: Lwiza@ksu.edu and lwizaflorence@gmail.com

\section{Johnny Mugisha}

Professor, Department of Agribusiness and Natural Resource Economics, Makerere University PO Box 7062 Kampala, Uganda.

Telephone number: +256 7773155702

Email.jomugisha@caes.mak.ac.ug

\section{Peter N Walekhwa}

Lecturer, Department of Agribusiness and Natural Resource Economics, Makerere University PO Box 7062 Kampala, Uganda.

Telephone number: +256 701511654

Email.walepet@caes.mak.ac.ug

\section{Bedru Babulo Balana}

Researcher-Economics

International Water Management Institute (IWMI), Accra, Ghana.

Tel: +233 (0) 268580790

Fax: +233 (0)302 784752

Email: B.Balana@cgiar.org

\section{Jo Smith}

Professor, Institute of Biological and Environmental Sciences

Aberdeen University

Telephone: +44 (0) 1224272702

Email: jo.smith@abdn.ac.uk

\section{*Corresponding author}




\begin{abstract}
The study analyses dis-adoption of biogas technologies in Central Uganda. Biogas technology makes use of livestock waste, crop material and food waste to produce a flammable gas that can be used for cooking and lighting. Use of biogas technology has multiple benefits for the households since it reduces the need for fuelwood for cooking and also produces bio-slurry which is a valuable fertilizer. Despite efforts by Government and Non-Governmental Organizations to promote the biogas technology, the rate of its adoption of biogas technology was found to be low, estimated at 25.8 percent of its potential. A review of literature showed that the households that dis-adopted biogas technology, did so within a period of 4 years after its installation, yet the lifespan of using it is estimated at 25 years. There was need to examine the factors contributing to dis-adoption. Using cross sectional data collected from Luwero and Mpigi districts found in Central Uganda, a probit model was estimated. The findings showed that an increase in the family size, the number of cattle, number of pigs and the age of the household head reduced the likelihood of biogas technology disadoption. Other factors that contributed to dis-adoption included the failure to sustain cattle and pig production that are necessary for feedstock supply, reduced availability of family labor the and inability of the households to repair biogas digesters after malfunctioning. Based on the findings, it was concluded that long term use of biogas technology required improved management practices on the farm so as to sustain livestock production. It is also recommended that quality standards and socio-cultural factors be considered in the design of biogas digesters and end use devices.
\end{abstract}

\title{
Highlights
}

- There are very low rates of uptake of biogas technology, but with very high rates of its disadoption.

- The design of end use devices impacts on the acceptability and usability of biogas technology.

- Long term use of biogas technology requires minimizing the risks that influence household labor supply and ownership of livestock.

\section{Key words}

Dis-adoption, Abandonment, biogas technology, anaerobic digesters. 


\subsection{Introduction}

In order to reduce dependency on wood and fossil fuels, energy sources such as biogas have been used in both rural and urban areas. Biogas is produced through anaerobic digestion of livestock waste, human waste, bio-degradable domestic waste, municipal waste and plant material [1]. The digestion process also results in the production of bio-slurry, a bi-product that is used as an organic fertilizer [2].

In Uganda, biogas technology was introduced in the 1950s and since then, there have been many initiatives by private individuals, Non-Governmental Organizations (NGOs), Government and different development partners to promote the technology [3]. These include pilot demonstrations, capacity building and provision of subsidies to households so as to increase uptake. Farm based biogas digesters with a capacity ranging between 5-10 $\mathrm{m}^{3}$ are the most widely used. Common designs include a floating drum, fixed dome and tubular design [4].

Despite the concerted efforts made to promote the use of biogas technology in Uganda, the rate of its uptake in the country is low [1], [4]. A feasibility study by Renwick et al. [5] estimated the potential to install biogas plants in Uganda at 20,000 yet by 2013, only 5168 plants had been constructed [6,7] thus realizing 25 percent of its potential. Mwirigi et al.[8], Mulinda et al. [4] and Walekhwa et al. [9] investigated factors affecting biogas technology adoption in Sub-Saharan Africa and cited economic barriers to investment as major inhibitors to adoption. However, even when financial burdens are lifted through subsidies, the users do not sustain use of the technology [10]. Nabuuma \& Okure [11] conducted a field study in Central Uganda and found out all the tubular biogas digesters that had been adopted were abandoned within four years after installation. In addition, 80 percent of the households that had abandoned the use of the fixed dome biogas digesters, did so within less than four years after completion of their construction. Kabarole Research Centre [12] also conducted a field study in Central, Eastern and Western Uganda and found out that some households stopped using the biogas digesters within 6 months after installation. It is estimated that households should be able to use the tubular biogas digesters for at least 5 years and the fixed dome biogas digesters for at least 25 years [13]. Therefore, the benefit for investment is not fully realized by the government and NGOs that provide subsidies for investment, and also by the households that invest their resources to take up the technology. 
The purpose of this study therefore was to examine the reasons for dis-adoption of biogas technology. Primary data was obtained by conducting household surveys in two selected districts of Mpigi and Luwero. The data was analyzed by using a probit regression model where the dependent variable took on two values; whether a household that previously adopted the biogas technology abandoned it or is still using it. The findings are presented and discussed in the proceeding sections.

\subsection{Review of literature}

There are numerous studies that assess the factors that affect adoption of new farm technologies. However, few studies have examined the rate and determinants of technology dis-adoption. In regards to biogas technology, studies by Kabir et al. [14], Mwirigi et al. [15] and Walekhwa et al. [9] show that variables such as the education level of the household head, farm income, land size and number of cattle have been found to positively influence adoption, whereas the variables such as gender and age of the household head have been found to negatively influence adoption, where by the older farmers and the male headed households were less likely to adopt the technology. Mwirigi et al. [8] also showed that the household's socioeconomic status influences adoption but it did not significantly influence the long term utilization of a biogas digester. However, Mulinda et al. [4] and Kabir et al. [14] show that many of the households that adopted biogas technology abandoned it including the households that were in the high income status. Puzzollo et al. [16] reviewed the barriers to sustained use of renewable energies, such as biogas, and concluded that the ability to meet cooking needs, being able to pay for a clean stove and fuel, having access to a reliable and affordable fuel supply and ensuring safe operation are the major conditions for adoption and sustained use of the technologies. Rogers [17] cited replacement of an old technology by a new one and disenchantment with a technology as reasons for dis-adoption. A common feature of these studies is that their findings and conclusions were based on qualitative analyses. There is therefore a paucity of quantitative empirical research on dis-adoption of biogas technology.

Empirical research has, however, been conducted on related technologies by applying the expected utility theory that treats dis-adoption as a dichotomous choice; whether to continue using a technology or abandon it. Neill \& Lee [18] examined the adoption and dis-adoption of maizemucuna farming systems in Honduras while Rahim et al. [19] studied the adoption and dis-adoption of gum Arabic production in Sudan. The models for these two studies were based on two discrete decisions; whether to adopt and, for those who adopted, whether to abandon. They employed 
bivariate probit models so as to account for the dichotomous nature of the decisions and the potential correlation between the decisions. Moser \& Barret [20] employed a simple probit model when studying the dis-adoption of rice production. The findings from the studies that have been reviewed show that dis-adoption of biogas technology can be studied using both qualitative and quantitative approaches and that a number of social, economic and technological factors influence its disadoption.

\subsection{Materials and methods}

\subsection{Study area}

The study was undertaken in two districts of Central Uganda; Mpigi and Luwero. Mpigi district is located to the West of Kampala, the capital city and along the shores of Lake Victoria whereas Luwero district located North West of Kampala. Mpigi District covers an area of 3,714 square kilometers which is about $0.16 \%$ of the country size. In 2014, the population of Mpigi District was estimated at approximately 250,548 and comprised of 60,511 households [21]. The total area of Luwero district is approximately 2577.49 square kilometers and the population of the district was estimated at 456,958 in 2014, and comprising of 105,346 households [21]. In the two districts, farming is dominated by smallholder farmers engaged in food and cash crops, horticulture, fishing and livestock farming. The major fuels used for cooking in rural areas are firewood and charcoal whereas for lighting, kerosene and solar energy are predominantly used.

Mpigi and Luwero districts were selected because they were some of the districts where the Uganda Domestic Biogas Program (UDBP) has been implemented. UDBP is a component of the Africa Biogas Partnership Program that brings together Non-Governmental Organizations, biogas construction companies, financial institutions and government agencies so as to develop and disseminate domestic biogas plants for use in rural and semi-urban areas. UDBP works in collaboration with the Ministry of Energy \& Mineral Development, Ministry of Agriculture, Animal Industry and Fisheries, and the Ministry of Water and Environment that are responsible for formulating policies that govern the use of renewable energies [6]. Between 2009 and 2013, 5168 biogas digesters had been installed under the UDBP but this was less than the targeted number of 12,000 installations country wide [6]. 


\subsection{Data collection}

Within the study areas, a total of 174 households were interviewed and these comprised three categories as summarized in Table 1.

\section{Table 1. Categories of households surveyed}

\begin{tabular}{llccc}
\hline \multicolumn{1}{c}{ Categories } & Luwero district & Mpigi district & Total \\
\hline (i) & $\begin{array}{l}\text { Households that adopted biogas technology } \\
\text { and were still using it }\end{array}$ & 8 & 35 & $\mathbf{4 3}$ \\
(ii) $\begin{array}{l}\text { Households that had dis-adopted biogas } \\
\text { technology }\end{array}$ & 30 & 10 & $\mathbf{4 0}$ \\
\hline $\begin{array}{l}\text { Total number of households that installed } \\
\text { biogas technology }\end{array}$ & $\mathbf{3 8}$ & $\mathbf{4 5}$ & $\mathbf{8 3}$ \\
\hline (iii) & $\begin{array}{l}\text { Households that have never adopted biogas } \\
\text { technology }\end{array}$ & 50 & 41 & $\mathbf{9 1}$ \\
\hline & Total number of households surveyed & $\mathbf{8 8}$ & $\mathbf{8 6}$ & $\mathbf{1 7 4}$ \\
\hline
\end{tabular}

The households that were considered as dis-adopters are those had not used the technology for at least 8 months by the time the survey was conducted. Given that there are few households that have biogas technology in the two districts, the households that were using the technology and those that had dis-adopted were purposively selected. The households that have never adopted were randomly selected.

Prior to the administration of the questionnaires, pretesting was done with 10 households so as to check the appropriateness of the questionnaires. The pretesting was carried out in September 2015 and the survey conducted for four weeks between October and November 2015. Questions were asked in Luganda which is the local language and the responses were recorded in English.

In-depth interviews were also conducted with 10 households that were using biogas technology and 10 households that had dis-adopted biogas technology in order to find out the challenges faced in the use of biogas technology and reasons for dis-adoption. Interview schedules that comprised both open ended and closed ended questions were used so to guide the discussions. 


\subsection{Data analysis}

\subsubsection{Conceptual framework and empirical model}

According to the random utility theory, a consumer makes a choice that maximizes his or her utility [22]. A household adopts biogas technology if the expected utility from using it is greater than the utility of not using it. Similarly, a household decides to dis-adopt a technology when the expected utility from continuing to use a technology is lower than the expected utility from discontinuing it. Assuming that households maximize utility, the decision by a farm household $i$ in year $t$ to dis-adopt biogas technology $\left(B T_{i t}=1\right)$ or to continue using it $\left(B T_{i t}=0\right)$ is based on a comparison of expected utilities of both situations. Using the difference in expected utilities gives the following decision rule:

$B T_{i t}=\left\{\begin{array}{l}1 \text { if } E\left(U_{i t}^{1}-U_{i t}^{0} \mid X_{i t}\right)>0 \\ 0 \text { if } E\left(U_{i t}^{1}-U_{i t}^{0} \mid X_{i t}\right) \leq 0\end{array}\right.$

where $E$ is the expectation operator, $U_{i t}^{1}$ denotes the utility of discontinuing the use biogas technology (dis-adoption) and $U_{i t}^{0}$ is the utility of continuing to use it. Households differ in the way they form expectations of the utility levels of both choices and these differences are due to characteristics of the household. The vector $X_{i t}$ accounts for variables that are assumed to have an impact on the utilities of both choices and the way expectations are formed on these utilities.

The expected difference in utility $E\left(U_{i t}^{1}-U_{i t}^{0} \mid X_{i t}\right)$ can be written as a latent variable $Y_{i t}^{*}$. Since utility is not directly observable, $Y_{i t}^{*}$ is also unobserved. Assuming that there is a linear relationship between expected utility differences and a vector of $X_{i t}$ variables that cause these differences, we can write

$Y_{i t}^{*}=E\left(U_{i t}^{1}-U_{i t}^{0} \mid X_{i t}\right)=X_{i t} \beta+\varepsilon_{i t}$

where $\beta$ is a vector of coefficients to be estimated by maximum likelihhod and $\varepsilon_{i t}$ are the error terms that are independent and normally distributed $(\varepsilon \sim N(0,1))$. Using the decision rule to discontinue using biogas technology as given by equation (1), we combine (1) and (2) into

$$
\operatorname{Pr}\left(B T_{i t}=1\right)=\operatorname{Pr}\left(Y_{i t}^{*}>0\right)=\operatorname{Pr}\left(X_{i t} \beta+\varepsilon_{i t}>0\right)=\operatorname{Pr}\left(-\varepsilon_{i t} \leq X_{i t} \beta\right)=F\left(X_{i t} \beta\right)
$$

where $\operatorname{Pr}$ denotes probability that a household discontinues to use biogas technology, and $F\left(X_{i t} \beta\right)$ is a cumulative distribution function. In empirical work, if a distribution function from the standard normal distribution is used, it leads to a probit model. 
The maximum likelihood estimate of the coefficients is calculated by setting up the log-likelihood function.

$\ln L=\sum_{1}\left[\ln \left(P\left(U_{i t} \geq-\beta X_{i t} \mid Y_{i t}^{*}=1\right)\right)\right]+\sum_{o}\left[\ln \left(P\left(U_{i t} \geq-\beta X_{i t} \mid Y_{i t}^{*}=0\right)\right)\right]$

Where $\sum_{1}$ and $\sum_{0}$ indicate the sum of all probabilities for those data points where $Y_{i t}^{*}=1$ and $Y_{i t}^{*}=0$ respectively. When a standard normal distribution is used to find the probabilities, it leads to a probit model.

$\beta$ is the effect of $X_{i t}$ on $Y_{i t}^{*}$. The marginal effect of $X_{i t}$ on the probability of dis-adoption $\mathrm{P}\left(Y_{i t}^{*}=1\right)$ is given by $f\left(\beta_{1} X\right) \cdot \beta_{1}$

The statistical software package STATA 12 was used to generate the maximum likelihood coefficients, standard errors and probability values.

\subsubsection{Empirical modeling}

From the review of literature, the factors that affect biogas technology adoption were socioeconomic and farm specific. It was hypothesized that the same factors are likely to influence disadoption. The equations below represent the general form of the decisions modeled below.

$$
Y_{i t}=\beta_{o}+\beta_{1} A G E+\beta_{2} H H S+\beta_{3} C A T+\beta_{4} L A N+\beta_{5} P I G+\beta_{6} F I N+\beta_{7} O F F+\varepsilon_{1}
$$

where $Y_{i t}$ is the dependent variable which denotes the household's decision to continue or dis-adopt the use of biogas technology (it takes on the value of 1 if the household dis-adopted and 0 otherwise), $\beta_{0}$ is a constant, $\beta_{1}$ to $\beta$ 7are the coefficients from the estimation and $\varepsilon_{1}$ is error term. The independent variables and their expected effect on the dependent variable are explained in Table 2. 
Table 2. Description of explanatory variables

\begin{tabular}{llc}
\hline $\begin{array}{l}\text { Explanatory } \\
\text { variable }\end{array}$ & Description & $\begin{array}{c}\text { Expected sign for } \\
\text { Dis-adoption }\end{array}$ \\
\hline AGE & $\begin{array}{l}\text { Age of the household head } \\
\text { Size of the land owned by the household measured in } \\
\text { hectares. }\end{array}$ & - \\
HHS & Number of persons in the households & - \\
CAT & Number of cattle & - \\
PIG & Number of pigs & - \\
FIN & Farm income measured in Uganda Shillings \\
OFF & $\begin{array}{l}\text { Participation in off-farm employment which is a } \\
\text { dummy variable where OFF =1 if the household head }\end{array}$ & $-/+$ \\
& has employment away from the farm and 0 otherwise. & \\
\hline
\end{tabular}

The hypothesized effect of land size on dis-adoption of biogas technology was both positive and negative. Land is a proxy for wealth and is also important for the sustenance of livestock as it can be used to as grazing grounds [23]. If livestock production is sustained, then the household can continue to use biogas because it will have enough feedstock for its production. On the other hand, a household having a large size of land may imply that it is able to plant trees and have woodlots that act as alternative sources of energy for cooking; such households are less likely to prioritize the use of biogas technology.

Whereas Kabir et al. [14] revealed a positive relationship between age and the likelihood of biogas technology adoption, we hypothesized that age was negatively correlated with dis-adoption as older farmers are more likely to appreciate the benefits of the technology since their ability to collect firewood is reduced.

The family size was measured by the number of persons in the household and it was hypothesized to negatively influence dis-adoption. This is because the family size is a proxy of household labor supply [24] which is required for livestock production and also for operation of the biogas plant. 
The number of cattle or the number of pigs owned by the household symbolize the wealth status of the household and also the supply of feedstock for biogas production. They are therefore hypothesized to negatively influence dis-adoption of biogas technology.

Sources of off-farm income in Uganda include employment in urban centers and petty trade activities. These off-farm activities often compete with the operation of a biogas plant for labor time. If off-farm income is high, the household head could spend more time off-farm than on-farm, which affects the operations of the biogas plant. Some empirical studies confirm that off-farm income increases the likelihood of dis-adoption such as Rahim et al. [19], and Moser \& Barrett [20]. On the other hand, the income earned from off-farm employment could be reinvested into livestock production that is necessary for feedstock supply or used for repairs and maintenance of the biogas digester and appliances. Therefore, there could be positive or negative relation between dis-adoption and off-farm income.

According to Suri [25], farm profits promote technology adoption whereas losses cause disadoption. In this study the effect of farm profit on biogas dis-adoption is studied and it is hypothesized that households with high farm returns are less likely to dis-adopt the technology. This is because the returns can be a resource to finance maintenance and other operational costs. However, profit could also create a disincentive to continue to use the technology if labor is diverted from the biogas operation to the more profitable enterprise. Therefore, it is difficult to hypothesize the effect of farm profit on the dis-adoption of biogas technology.

\subsection{Results and Discussions}

The findings presented in this section summarize the characteristics of the households, the factors influencing dis-adoption of the biogas technology and the stated reasons for abandonment.

\subsection{Farm and household characteristics}

The one-way Analysis of Variance (ANOVA) was used to determine whether there are any statistically significant differences between the means for the continuous variables for the three groups of respondents who included the households that adopted and still use biogas, households that dis-adopted and the households that have never adopted biogas technology. ANOVA was used to the null hypothesis that there was no significant difference in the means for the three groups; i.e.

$$
H_{O}: \mu_{1}=\mu_{2}=\mu_{3}
$$


where $\mu$ = group mean

The use of ANOVA is based on three main assumptions; independence of observations, normality of the dependent variable and homogeneity of the variances in each group that is being compared. The results are presented in table 3.

Table 3. Farm and household characteristics

\begin{tabular}{|c|c|c|c|c|}
\hline Continuous Variables & $\begin{array}{l}\text { Households } \\
\text { that } \\
\text { Adopted } \\
(n=43)\end{array}$ & $\begin{array}{l}\text { Households } \\
\text { that Dis- } \\
\text { adopted } \\
(n=40)\end{array}$ & $\begin{array}{l}\text { Households } \\
\text { that never } \\
\text { adopted } \\
(n=91)\end{array}$ & ANOVA \\
\hline $\begin{array}{l}\text { Mean Age of household head (completed } \\
\text { number of years) }\end{array}$ & $55^{*}$ & 50 & 43 & 0.000 \\
\hline $\begin{array}{l}\text { Mean for Household size (number of } \\
\text { persons) }\end{array}$ & $7^{* *}$ & 6 & 6 & 0.092 \\
\hline $\begin{array}{l}\text { Mean Household labor (number of persons } \\
\text { that provide labor for household and farm } \\
\text { activities) }\end{array}$ & 5 & 4 & 4 & 0.136 \\
\hline Average number of cattle & $4^{*}$ & 1 & 1 & 0.000 \\
\hline Average number of pigs & $12^{*}$ & 7 & 3 & 0.004 \\
\hline Mean land size (Hectares) & $2.64^{*}$ & 2.06 & 1.12 & 0.000 \\
\hline $\begin{array}{l}\text { Annual farm income (Millions of Uganda } \\
\text { shillings) }\end{array}$ & 2.80 & 2.60 & 2.85 & 0.859 \\
\hline Categorical variable & & & & $\begin{array}{l}\text { Chi- } \\
\text { square test }\end{array}$ \\
\hline Participation in off-farm employment (\%) & 51.16 & 52.50 & 61.53 & 1.615 \\
\hline
\end{tabular}

The results show that the mean age of the household head was statistically different for the three groups $(\alpha=0.000)$ with the adopter group having the highest mean age.

The mean household size for the households that adopted and those that never adopted biogas technology was 6 persons as compared to the adopter group that had 7 persons. The results showed that mean size of the household was significantly different for the three groups at 10 percent significance level $(\alpha=0.092)$. However, there was no significant difference in the mean of the number of persons that offered labor within the household. 
The results further showed that that the households that adopted biogas technology had the highest mean number of cattle and the number of pigs estimated at 4 and 12 respectively. The mean number of cattle and pigs was statistically different for the three groups at 1 percent significance level.

The size of the land owned by the household was highest for the adopters, estimated at 2.64 hectares whereas that for the non-adopters and dis-adopters was, it was 1.12 and 2.06 hectares respectively. The mean land size for all the groups was 1.70 hectares. The land size was statistically different for the three groups as shown by both the results of the ANOVA test.

Participation of the household head in off-farm employment was a categorical variable showing whether or not a household head had employment away from the farm. The results of the Pearson chi-square test showed that there was no association between the off-farm employment for the household head and the status of adoption for the three categories of the households.

\subsection{Status of biogas technology adoption and dis-adoption}

The survey findings showed that there was an increase in the number of households that installed biogas technology over the years. This was as a result of the increased efforts to promote the technology by different NGOs. The NGOs provided subsidies for investment and also put up demonstration plants to encourage the communities to adopt. In the study area, all households installed fixed dome digesters whose lifespan is estimated to be more than 20 years [13], [27], [28]. However, the survey findings showed that in Luwero district, households used the biogas digesters for an average of 3.5 years before abandonment. Adoption of biogas technology in Luwero district started in 1994 but with majority of the household taking up the technology between 2003 and 2009. By the time the survey was conducted in 2015, 79 percent of the households had dis-adopted. In Mpigi district, many of the biogas digesters were installed between 2011 and 2014. By the time the survey was conducted in 2015, 29 percent of the households had dis-adopted and this was within an average time period of 1.8 years after installation.

As the number of households that installed biogas technology increased, so did the number of households that dis-adopted it as illustrated in Fig. 1 and 2. However, in Luwero district, 4 respondents from the households that dis-adopted biogas technology could not recall the year in which they stopped using the technology. They were therefore not included in the analysis shown in Fig. 2. 


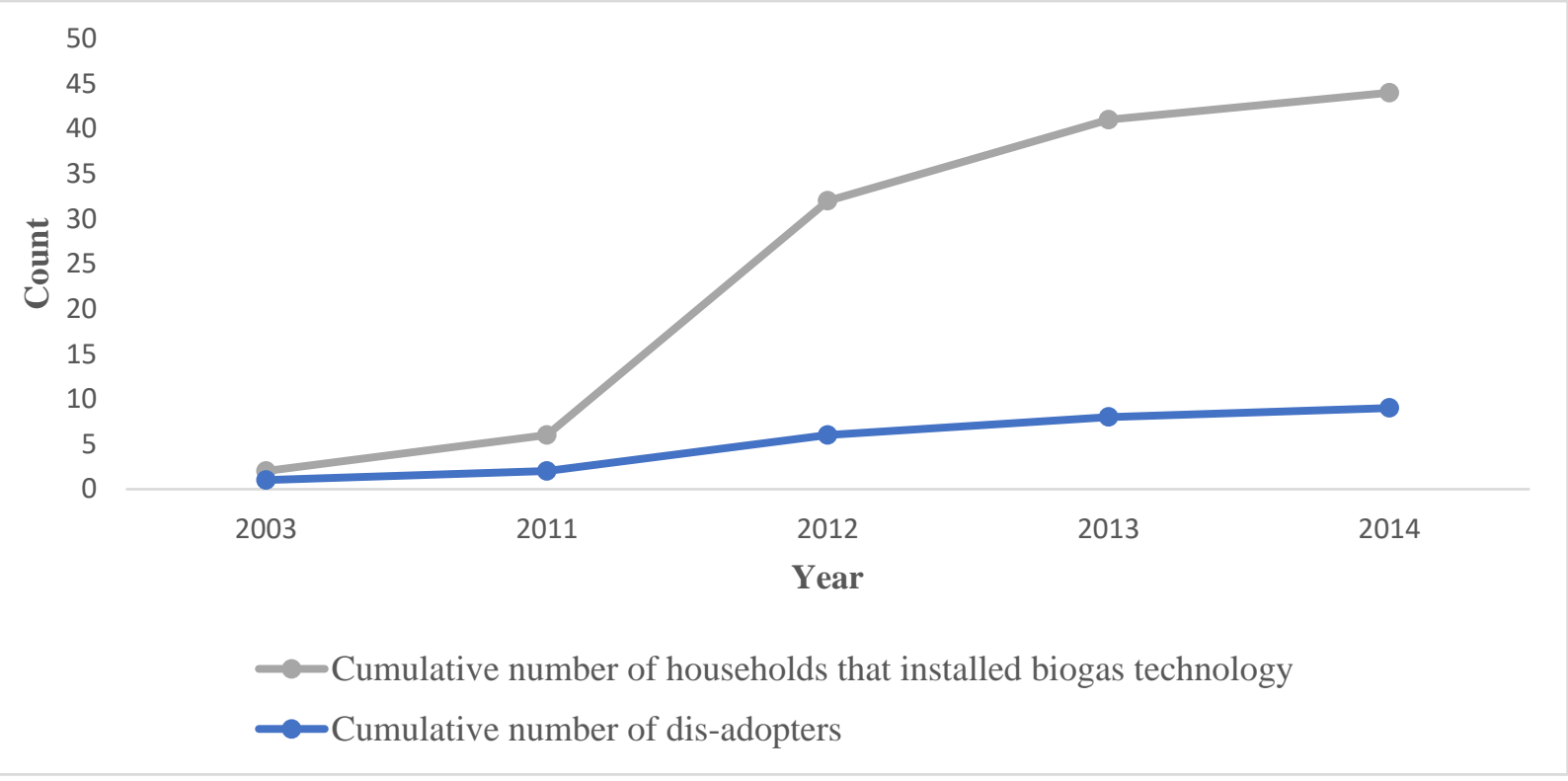

Figure 1. Cumulative number of biogas installations and dis-adopters in Mpigi district

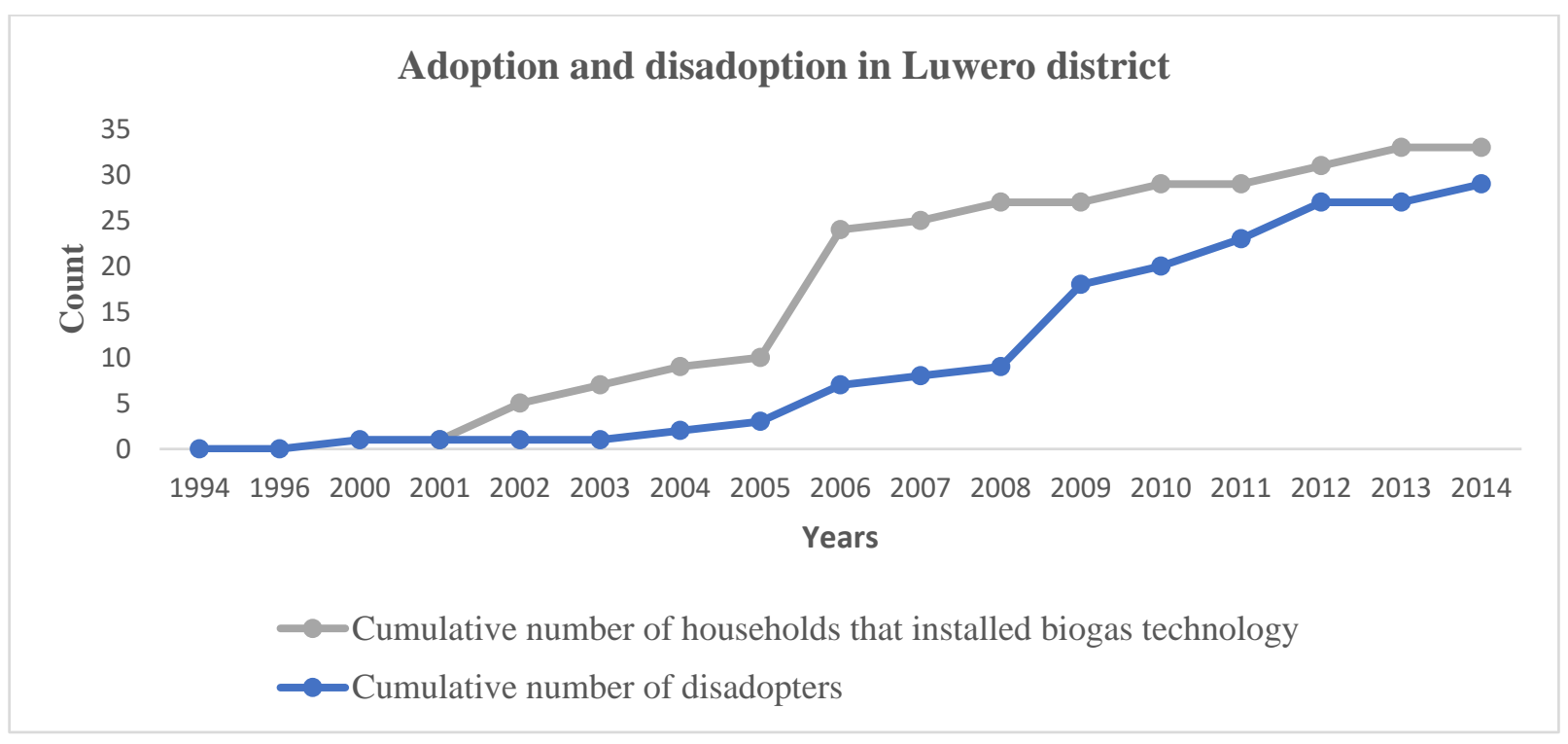

Figure 2. Cumulative number of biogas installations and dis-adopters in Luwero district 


\subsection{Determinants of biogas technology dis-adoption}

The marginal effects of the changes in the independent variables on the probability of dis-adoption are summarized in Table 4.

The size of the land holdings was found to be significant and positively associated with dis-adoption of biogas technologies. The findings showed that an increase in the land size increases the probability of dis-adoption by 7.13 percent. Land is one of the symbols of household wealth, and it shows the household's ability to afford investment of the biogas digester; the findings of Mwirigi et al. [15] indicated that the size of the family land and the adoption of the technology had a statistically significant and positive relationship, with the bulk of the biogas plant owners having between 0.81 and 4.05 hectares of land unlike majority of the non-plant owners who owned less than 0.81 hectares. However, households with large pieces of land are also able to plant trees and have woodlots. They are therefore less likely to prioritize the use of biogas technology since they are able to get firewood at no cash cost [23].

The size of the household was significant and negatively associated with the probability of disadoption of biogas technology. This is because most of the work required to operate the biogas digester is provided by family members and not hired labor [15]. The results showed that, holding other factors constant, a unit increase in family size reduces the probability of dis-adoption by $4.5 \%$ of the marginal effect. This finding is in agreement with the study conducted by Christiaensen \& Heltbergy, [23] which showed that biogas technology is not suitable for households with limited labor supply. Households with larger family sizes that have more labor to carry out the activities required for the operation of the biogas plant and also to take care of the livestock from which feedstock is obtained.

The age of the household head was found to be significant and negatively influencing dis-adoption. This can be attributed to the increased need for biogas, given that the labor input into collecting firewood is likely to reduce as age increases. This research finding, however, contrasts that by Rahim et al. [19] and Moser and Barrett [20], who showed that older farmers dis-adopt technologies more frequently because the age reduces their labor input.

The number of pigs or cattle are important for provision of feedstock and therefore a prerequisite for continued use of the biogas technology [14], [23]. Walekhwa et al. [27] state that at least 2 cattle 
or 6 pigs are required to operate a family sized biogas digester. This was confirmed by our research findings, where the number of pigs and number of cattle were found to be significant at 5 percent and negatively influencing dis-adoption. A unit increase in the number of cattle reduces the probability of dis-adoption by 13.13 percent whereas a unit increase in the number of pigs owned by the household reduces the probability of dis-adoption by 4.10 percent.

Participation of the household head in off-farm activities off farm activities and the size of the land holding owned by the household were found to positively influencing the probability dis-adoption but were not significant. The whole farm profitability was found to be negatively influencing disadoption but was also not significant.

Table 4. Determinants of biogas technology disadoption

\begin{tabular}{lllll}
\hline Disadoption & Coefficient & $\begin{array}{l}\text { Marginal } \\
\text { effect }\end{array}$ & $\begin{array}{l}\text { Standard } \\
\text { Error }\end{array}$ & $\mathbf{P}>|\mathbf{z}|$ \\
\hline Number of pigs & $-0.1084^{* *}$ & -0.0409 & 0.0443 & 0.014 \\
Age of the household head & $-0.0441^{* *}$ & -0.0166 & 0.0183 & 0.016 \\
Household size & $-0.1200^{* * *}$ & -0.0452 & 0.0707 & 0.084 \\
Number of cattle & $-0.3485^{* *}$ & -0.1313 & 0.1383 & 0.012 \\
Land size holding & 0.1891 & 0.0712 & 0.1120 & 0.091 \\
Off farm & 0.4260 & -0.1603 & 0.3914 & 0.276 \\
Farm income & -0.0016 & -0.0000 & 0.0001 & 0.141 \\
Constant & $3.5681^{*}$ & & 1.0161 & 0.000 \\
\hline
\end{tabular}

Number of obs $=83$

LR chi2(7) = 31.69

Pseudo R2 $=0.3416$

Prob $>$ chi $2=0.0000$

*Significant at the 0.01 level $(\mathrm{p}<0.01)$

**Significant at the 0.05 level $(\mathrm{p}<0.05)$

*** Significant at the 0.1 level $(\mathrm{p}<0.1)$

\subsection{Stated reasons for dis-adoption of biogas technology use}

The findings from the survey and interviews showed that the reasons for biogas technology disadoption were technological, social and economic as presented in Table 5. 
Table 5. Stated reasons for dis-adoption

Stated reasons for dis-adoption
Number of households

Mpigi Luwero

district district

Non-functional biogas digester installations and end use devices

Low motivation to undertake repairs as a result of inadequate gas production

2

3

Unable to access shops for replacement of spoilt or stolen components

2

7

Unable to access technicians and masons for repairs

1

5

Failure to sustain livestock production

Theft of livestock

Death of livestock as a result of epidemics

Sold livestock so to meet household needs

Land use changes made it difficult to sustain feeding for cattle

Redistribution of livestock as property for inheritance after death of household head

12

12

1

Reduced supply of family labor

Reduced supply of household labor as a result of progress with education

Reduced supply of household labor as a result of mobility in search of paid employment off-farm.

Preferences for alternative fuels

Emergence of alternative energy sources for lighting

Biogas Cook stove were not favorable for the cooking pots and methods used for food preparation

Failed to stock dung required for the initial feeding of the digester

1

One of the reasons for dis-adoption of biogas technology was that some components of the biogas technology were non-functional, damaged or stolen. The members of the households were not able to have them repaired or replaced because the technicians and shops for the replacement of appliances were inaccessible. During the installation for the digesters, the construction materials, appliances and technicians were provided by the NGOs that were promoting the technology. The 
households never got know where the shops for biogas appliances were located. In addition, there was a lack of motivation for repairs because for some households, the technology did not meet the expected cooking and lighting needs of the household. The interview findings showed that the requirement for an average household of six persons was to have at least an average 3 hours of cooking per day and 6 hours of lighting per day; yet the respondents stated that they realized only 1 hour of cooking or 4.5 hours of lighting per day. Therefore, the use of biogas did not fully replace the use of other fuels as was anticipated by the households before adoption.

In utilizing biogas digesters, labor is required for collection of water, mixing feedstock, feeding the plant and transportation to the bio-slurry to the gardens [4], [8]. Where labor cannot be hired, women and children provide most of this labor, since they are considered to have the sole responsibility for domestic work and energy availability within the household. During the interviews, the respondents stated that they dis-adopted biogas technology because the labor supply from the children reduced over time. As the children progressed with their education, they attended distant schools and boarding schools, and thereafter found employment away from the farms. Therefore, households that were initially able to sustain livestock production and use of biogas technology were no longer able to do so because of reduced supply of family labor. On the other hand, households that were using biogas technology were able to reduce the labor requirement for collecting water for biogas use by using alternatives such as cattle urine, human urine and harvested rain water. Cattle sheds were constructed in a way that they had concrete to ease collection of dung and were also gently sloping, with outlets to ease the collection of urine as shown in Figure 3 and 4. Collection of urine reduced the need to collect water for feedstock production. Therefore, good design and layout of animal housing and the biogas units can be one way of reducing the labor needed to feed and process feedstock. 


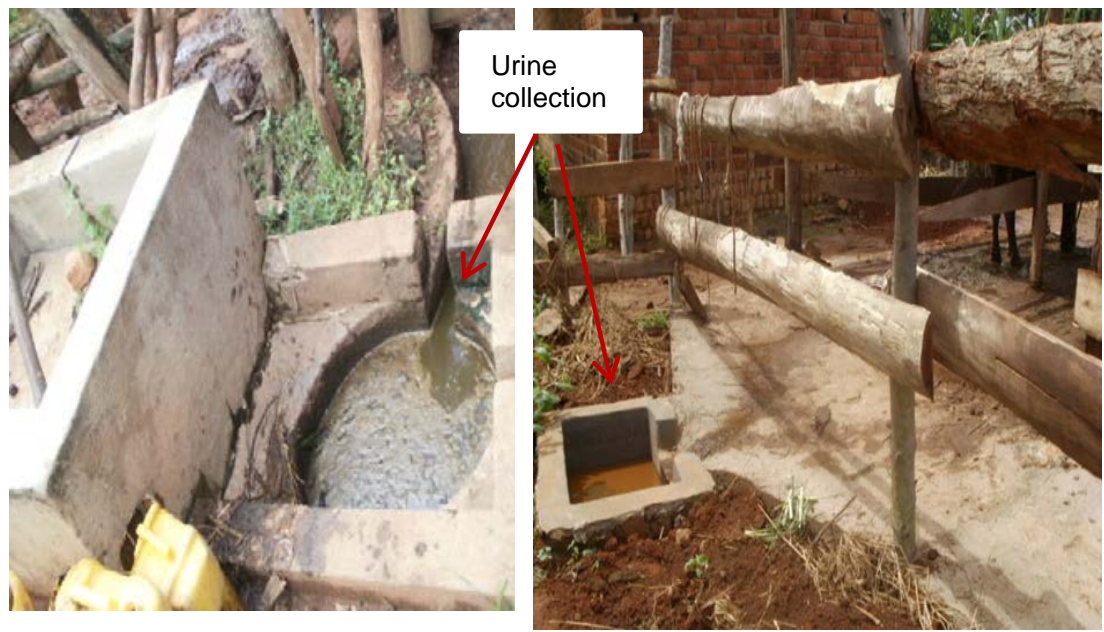

Figure 3. Cattle sheds constructed with urine collection centers

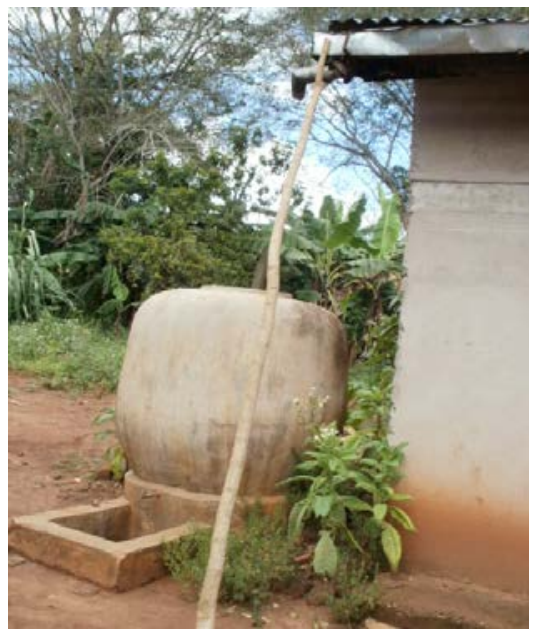

Figure 4. Tank for rain water harvesting

The inability to sustain livestock production was one of the major reasons stated for dis-adoption of biogas technology. The inability to sustain cattle and pig production was as a result of sales and calamities such as epidemic diseases and thefts. Interviews with respondents from the households that dis-adopted revealed that some households preferred to save their money inform of assets such as cattle and pigs, rather than money save in banks and other financial institutions. They therefore easily sold them off when faced with financial difficulties. On the contrary, majority of the respondents from the households that were using biogas technology stated that they were able to sustain cattle production because they earned an income from the sale of milk that was produced by the cows. The sales from milk generate daily income for the household that was used to meet the different needs for the households.

Some households sold off the land that was previously used for grazing cattle while others used it for infrastructure development. They therefore changed their cattle feeding strategy from the pasture range to the use of fodder and crop residues. Because of the limited land, they planted fodder crops as fences surrounding the homesteads and farm boundaries shown in Figure 5. The households that could not afford to have enough fodder to sustain the cattle sold them off. 

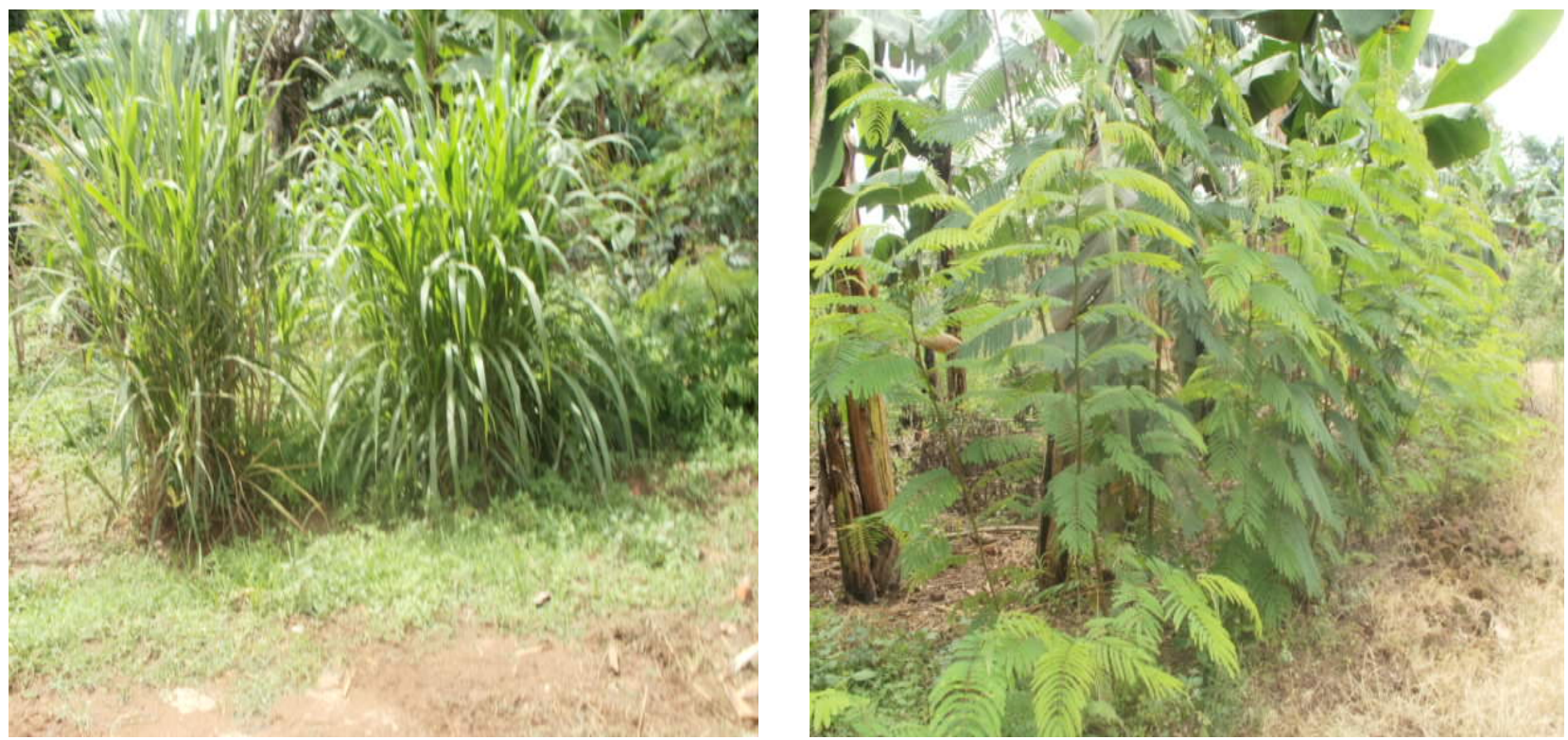

Figure 5. Planted fodder grasses and trees surrounding the farms

Some households dis-adopted biogas technology when they lost the pigs that used to supply dung for feedstock production. The pigs died as a result of being affected by swine fever, which is an epidemic disease for which there is no cure. Households could not restock pigs until the spread of the disease was under control. For some households, the cows and pigs that used to supply dung for biogas production were stolen. Therefore, the households were not able to restock livestock because of the high expenditure involved in purchasing new stock and also the fear that the animals could be stolen again.

Dis-adoption was also as a result of redistribution of household assets after the death of the household head. Assets such as land and livestock were inherited and shared amongst the different family members. Since the new owners of the assets were not aware or convinced of the benefits of biogas technology, then they sold them off or diverted them to other uses.

Some households dis-adopted because they failed to stock dung and water that are required for the initial feeding of a biogas digester. Smith et al. [30] estimate that the initial feeding for a biogas digester is two thirds of its capacity. It therefore required that the households that installed the $6 \mathrm{~m}^{3}$ biogas plants to have an initial feeding of $4 \mathrm{~m}^{3}$ of feedstock. The feedstock consists of dung and water that are mixed in equal proportions. The households that did not accumulate the required amount of feedstock never used the digesters after their installation. 
The findings also showed that biogas was not a perfect substitute for other cooking and lighting fuels. Solar and kerosene lamps were the mainly used for lighting even for the households that were using biogas energy. Households that adopted biogas technology hoped for use it for lighting more than one room and also for outdoor security lighting. However, because of limited biogas production, they were able to light only one biogas lamp for an average of 4.5 hours per day. The biogas lamps were also easily damaged by changes in weather and could not be used for outdoor lighting. The households therefore resorted to taking up alternative energy sources for lighting such as solar energy that were cheaper to install, could also be used to light many rooms for a longer period of time and could also be used for outdoor lighting.

In addition, respondents stated that using biogas technology was not worthwhile if it could not be used to cook the staple foods for the households. The taste of the food prepared using firewood was different from that when biogas was used for cooking. In addition, the size and design of the biogas cook stove did not suit the size of the pots that were used for cooking. The women respondents were interviewed further to explain the attributes that they desire about the other cooking stoves that they did not get with the biogas stove. The results of these interviews on the preferences for cooking stoves are summarized in Table 6.

\section{Table 6. Comparison of preference for the cooking stoves}

\begin{tabular}{|l|l|l|}
\hline Traditional 3 stone stove & $\begin{array}{l}\text { Improved firewood } \\
\text { cooking stove }\end{array}$ & Biogas stove \\
\hline & &
\end{tabular}




\begin{tabular}{|l|ll|l|}
\hline$\bullet$ & $\begin{array}{l}\text { Can accommodate } \\
\text { cooking pots of different } \\
\text { sizes. }\end{array}$ & $\begin{array}{l}\text { Can accommodate } \\
\text { cooking pots of different } \\
\text { sizes. }\end{array}$ & $\begin{array}{l}\text { Biogas stoves is limited to a } \\
\text { specific sizes of the cooking } \\
\text { pot. }\end{array}$ \\
\hline$\bullet \begin{array}{l}\text { Retains heat for at least 1- } \\
2 \text { hours after firewood has } \\
\text { burned out. }\end{array}$ & $\begin{array}{l}\text { Retains heat for at least } \\
\text { 2-4 hours after for } \\
\text { firewood has burned out. }\end{array}$ & $\begin{array}{l}\text { Does not retain heat after } \\
\text { the gas is switched off. }\end{array}$ \\
\hline $\begin{array}{l}\text { Can be used to cook foods } \\
\text { of varying weights }\end{array}$ & $\bullet \begin{array}{l}\text { Can be used to cook } \\
\text { foods of varying weights }\end{array}$ & $\bullet \begin{array}{l}\text { Is suitable for light weights } \\
\text { of food. }\end{array}$ \\
\hline
\end{tabular}

From the comparisons that were made, the improved wood fuel stove was more preferred as compared to the traditional and biogas stove. The biogas stoves could be made more acceptable if they could be modified so as to meet the diverse needs and preferences of the households.

\subsection{Conclusion and recommendations}

Basing on the findings of this study, it is important that efforts by the Government and NonGovernment Organizations should not only focus on increasing the number of installations of biogas technology, but also focus on increasing the acceptability and usability of the technology. It requires a holistic assessment of the resources, risks and preferences of the household. Long term use of biogas technology is also possible if the households' objectives for adoption are met and these include achieving significant reductions in the use of fuelwood and also reduction on the expenditure on lighting fuels. Based on the findings, the following recommendations are forwarded:

(i) Agencies that promote biogas technologies should endeavor to collect good baseline data before implementation of any program. The baseline data will enable the promoters to know what how each household is endowed with in terms of the required resources like land, labor, livestock and water. The baseline data should also indicate the risks that households are likely affect that may impact on the existence of the livestock and the supply of labor within the household. Once the implementing agencies understand the status of the targeted households, they can build appropriate incentives into their programs so as to overcome the households' limitations.

(ii) Government agencies in collaboration with the private sector and NGOs that promote biogas technologies should develop standards for biogas digesters and end use equipment. The standards clearly define levels for technology performance, quality as well as provide 
common terminology for understanding and communicating about the technology. Once the standards are developed, they ensure that they are implanted by the technology developers.

(iii) The biogas construction companies should offer appropriate information, user training and after sales services so as to minimize malfunctioning of the technology. They should also be able to link the households that adopt to the markets for biogas appliances.

(iv) All implementers of biogas technology interventions, including the private sector, NonGovernmental Organizations, and governments, should take into consideration the biogas user's needs and behavior as their starting point and these should inform every biogas technology intervention. A differentiated approach based on specific socio-cultural contexts is recommended so as to make the technology more preferable by the end users. Since women are the end users of the biogas cook stoves, they need to be involved in all stages of its development.

\section{Funding}

This work was supported by funding from the African Union Commission to the Afri-flame network under the project: Adaptation of small-scale biogas digesters for use in rural households in SubSaharan Africa, grant number AURG/2/058/2012.

\section{Acknowledgment}

Special thanks to Prof. Andrew Barley of Kansas State University for the comments and suggestions to improve the paper. Appreciation also goes to the extension staff and management of SCC-Vi Agroforestry in Central Uganda, who were instrumental during the household survey data collection. 


\section{References}

[1] B. Amigun, W. Parawira, and J. K. Musango, “Anaerobic Biogas Generation for Rural Area Energy Provision in Africa,” Biogas, p. 408, 2012.

[2] W. Parawira, "Biogas technology in sub-Saharan Africa: Status, prospects and constraints," Rev. Environ. Sci. Biotechnol., vol. 8, no. 2, pp. 187-200, 2009.

[3] M. Sengendo et al., "Programme implementation document for Uganda domestic biogas programme,” January, p. 72, 2010.

[4] C. Mulinda, Q. Hu, and K. Pan, "Dissemination and Problems of African Biogas Technology,” Energy Power Eng., vol. 2013, no. October, pp. 506-512, 2013.

[5] P. S. S. and G. H. Mary Renwick, "Biogas for better life: An African Intiative a cost benefit analysis of national and regional integrated biogas and sanitation programs in Subsaharan Africa, a draft final report Winrock International,” Africa (Lond)., no. April, 2007.

[6] MEMD, “MEMD Annual Report 2013,” MEMD Annu. Rep. 2013, p. 251, 2014.

[7] B. G. Mugerwa, "Uganda Domestic Biogas Programme (UDBP) A presentation to InterAction BPI Innitiative,” 2012.

[8] J. Mwirigi et al., "Socio-economic hurdles to widespread adoption of small-scale biogas digesters in Sub-Saharan Africa: A review,” Biomass and Bioenergy, vol. 70, pp. 17-25, 2014.

[9] P. N. Walekhwa, J. Mugisha, and L. Drake, "Biogas energy from family-sized digesters in Uganda: Critical factors and policy implications,” Energy Policy, vol. 37, no. 7, pp. 27542762, 2009.

[10] A. G. Mwakaje, "Dairy Farming and the Stagnated Biogas Use in Rungwe District, Tanzania: An Investigation of the Constraining Factors,” Biogas, pp. 311-326, 2012.

[11] B. Nabuuma and M. A. E. Okure, "Field-Based Assessment of Biogas, Technology: The Case of Uganda," in Proceedings from the International Conference on Advances in Engineering and Technology, 2006, pp. 481-487.

[12] KRC, “Gender and workload in Biogas adoption in Uganda.,” A case study, Kabarole Research Centre, Fortportal, Uganda, 2013.

[13] C. Nzila, J. Dewulf, H. Spanjers, D. Tuigong, H. Kiriamiti, and H. van Langenhove, "Multi criteria sustainability assessment of biogas production in Kenya,” Appl. Energy, vol. 93, pp. 496-506, 2012.

[14] H. Kabir, R. N. Yegbemey, and S. Bauer, "Factors determinant of biogas adoption in Bangladesh,” Renew. Sustain. Energy Rev., vol. 28, pp. 881-889, 2013.

[15] J. W. Mwirigi, P. M. Makenzi, and W. O. Ochola, "Socio-economic constraints to adoption 
and sustainability of biogas technology by farmers in Nakuru Districts, Kenya,” Energy Sustain. Dev., vol. 13, no. 2, pp. 106-115, 2009.

[16] E. Puzzolo, D. Pope, D. Stanistreet, E. A. Rehfuess, and N. G. Bruce, "Clean fuels for resource-poor settings: A systematic review of barriers and enablers to adoption and sustained use,” Environ. Res., vol. 146, pp. 218-234, 2016.

[17] E. M. Rogers, Diffusion of innovations. 1995.

[18] S. P. Neill and D. R. Lee, "Explaining the Adoption and Disadoption of Sustainable Agriculture: The Case of Cover Crops in Northern Honduras Explaining the Adoption and Disadoption of Sustainable Agriculture: The Case of Cover Crops in Northern Honduras*," Source Econ. Dev. Cult. Chang., vol. 4912713, no. 4, pp. 793-820, 2001.

[19] A.H. Rahim, R. Ruben, and E.C. van Ierland, “Adoption and Abandonment of Gum Arabic,” AFTA 2005 Conference proceedings pp. 1-16, 2005.

[20] C. M. Moser and C. B. Barrett, “The Complex Dynamics of Smallholder Technology Adoption :," Agric. Econ., vol. 35, no. 607, pp. 373-388, 2006.

[21] UBOS, “Statistical Abstract 2015,” Uganda Bureau of Statics, October 2015.

[22] J. Walker and M. Ben-Akiva, “Generalized random utility model,” Math. Soc. Sci., vol. 43, pp. 303-343, 2002.

[23] L. Christiaensen and R. Heltberg, "Greening China ’ s Rural Energy - New Insights on the Potential of Smallholder Biogas,” Policy Res. Work. Pap. 6102, Dev. Res. Group, Poverty Inequal. Team, World Bank, no. June, 2012.

[24] C. R. Doss, Understanding Farm-level Technology Adoption : Lessons Learned from CIMMYT’ s Micro Surveys in Eastern Africa Working Paper 03-07.

[25] T. Suri, "Selection and Comparative Advantage in Technology Adoption,” Econometrica, vol. 79, no. 1, pp. 159-209, 2011.

[26] S. G. Gwavuya, S. Abele, I. Barfuss, M. Zeller, and J. Müller, “Household energy economics in rural Ethiopia: A cost-benefit analysis of biogas energy,” Renew. Energy, vol. 48, pp. 202-209, 2012.

[27] P. N. Walekhwa, D. Lars, and J. Mugisha, "Economic viability of biogas energy production from family-sized digesters in Uganda,” Biomass and Bioenergy, vol. 70, pp. 26-39, 2014.

[28] K. Rajendran, S. Aslanzadeh, and M. J. Taherzadeh, Household biogas digesters-A review, vol. 5, no. 8. 2012.

[29] G. Otim, D. Okaka, and J. Kayima, "Design of biogas plant for rural household in Uganda (case study: Apac district),” Second international conference on advances in engineering and technology. pp. 481-487, 2006. 
[30] J. Smith et al., "The potential of small-scale biogas digesters to alleviate poverty and improve Long term sustainability of ecosystem services in Sub-Saharan Africa," 1st World Sustain. Forum, vol. 5, no. 10, pp. 2911-2942, 2013. 